\title{
Nitric oxide and prostaglandins potentiate the liver regeneration cascade
}

\author{
Jodi M Schoen Smith PhD, W Wayne Lautt PhD
}

\begin{abstract}
JM Schoen Smith, WW Lautt. Nitric oxide and prostaglandins potentiate the liver regeneration cascade. Can J Gastroenterol 2006;20(5):329-334.
\end{abstract}

The liver has the remarkable ability to regenerate following damage or surgical resection. Although this feature of the liver has been studied for over 100 years, the trigger of the liver regeneration cascade remains controversial. Recent experimental evidence supports the hypothesis that nitric oxide (NO) and prostaglandins (PGs), released secondary to an increase in the blood flow-to-liver mass ratio following two-thirds partial hepatectomy ( $\mathrm{PHx})$, work synergistically to trigger liver regeneration. To extend this research, the hypothesis that $\mathrm{NO}$ and PGs are potential therapeutic targets to potentiate the liver regeneration cascade is tested. The NO donor s-nitroso-n-acetylpenicillamine, the phosphodiesterase $\mathrm{V}$ antagonist zaprinast (ZAP) and $\mathrm{PGI}_{2}$ each potentiated $c$-fos messenger RNA expression, an index of initiation of the liver regeneration cascade, following PHx. Also, the triple combination of s-nitroso-n-acetylpenicillamine, ZAP and $\mathrm{PGI}_{2}$ potentiated $c$-fos messenger RNA expression. These results support the hypothesis that $\mathrm{NO}$ and PGs can potentiate initiation of the regeneration cascade. An additional index of liver weight restoration $48 \mathrm{~h}$ after $\mathrm{PHx}$ was also used to test the hypothesis, because this index encompasses the entire liver regeneration cascade. ZAP and 6keto-PGF $1 \alpha$, a stable metabolite of $\mathrm{PGI}_{2}$, and the combination of ZAP and 6 -keto-PGF ${ }_{1 \alpha}$, each potentiated liver weight restoration $48 \mathrm{~h}$ after $\mathrm{PHx}$. These results also provide support for the hypothesis that $\mathrm{NO}$ and PGs are possible therapeutic targets to potentiate liver regeneration following surgical resection.

Key Words: Liver regeneration; Nitric oxide; Prostaglandins; Two-thirds partial hepatectomy

R ecent research has provided support for the hypothesis that $R$ an increase in the blood flow-to-liver mass ratio that ensues with partial hepatectomy (PHx) results in increased shear stress in the liver, resulting in release of nitric oxide (NO) which triggers the liver regeneration cascade (1-4). In addition, there is evidence that prostaglandins (PGs) play a role in liver regeneration (5-7), and have been suggested to trigger the liver regeneration cascade (8).

Interaction between $\mathrm{NO}$ and $\mathrm{PGs}$ has been shown to be an important part of the liver regeneration cascade. Both $\mathrm{NO}$ and PGs increase after two-thirds PHx $(5,6,9,10)$, and inhibition of either $\mathrm{NO}$ or PG synthesis negatively affects liver regeneration $(8,11,12)$. In situations where either NO synthase or cyclooxygenase is inhibited, an excess amount of the other may be able

\section{L'oxyde nitrique et les prostaglandines poten- tialisent la cascade de régénérescence hépatique}

Le foie a la remarquable capacité de se régénérer après une lésion ou une résection chirurgicale. Bien que cette caractéristique ait été étudiée depuis plus de 100 ans, le déclencheur de la cascade de régénérescence hépatique ne fait toujours pas l'unanimité. De récentes expériences ont appuyé l'hypothèse selon laquelle l'oxyde nitrique (NO) et les prostaglandines (PG), libérés par suite d'une augmentation du rapport flux sanguin:masse hépatique après une résection partielle des deux tiers du foie (HP, hépatectomie partielle), agissent en synergie pour déclencher la régénérescence hépatique. Pour pousser la recherche plus loin, les auteurs ont voulu tester l'hypothèse selon laquelle le NO et les PG seraient des cibles thérapeutiques possibles pour potentialiser la cascade de régénérescence hépatique. Après une HP, la s-nitroso-n-acétylpénicillamine, productrice de $\mathrm{NO}$, l'antagoniste de la phosphodiestérase $\mathrm{V}$ zaprinast $(\mathrm{ZAP})$ et la $\mathrm{PGI}_{2}$, ont potentialisé l'expression de l'ARN messager c-fos, un indice du déclenchement de la cascade de régénérescence hépatique. En outre, la triple combinaison de s-nitroso-n-acétylpénicillamine, de ZAP et de $\mathrm{PGI}_{2}$ a potentialisé l'expression de l'ARN messager $c$-fos. Ces résultats appuient l'hypothèse du rôle potentialisateur du $\mathrm{NO}$ et des PG dans le déclenchement de la cascade de régénérescence. Un autre indice du rétablissement de la masse hépatique 48 heures après l'HP a aussi été utilisé pour tester l'hypothèse parce que cet indice englobe toute la cascade de régénérescence hépatique. Le $\mathrm{ZAP}$, la 6-kéto- $\mathrm{PGF}_{1 \alpha}$, un métabolite stable de la $\mathrm{PGI}_{2}$, et une combinaison des deux ont chacun potentialisé le rétablissement de la masse hépatique 48 heures après l'HP. Ces résultats corroborent également l'hypothèse selon laquelle le NO et les PG seraient de possibles cibles thérapeutiques pour potentialiser la régénérescence hépatique après une résection chirurgicale.

to compensate for the effects of the missing compound (Smith and Lautt, unpublished data).

Thus, it is hypothesized that $\mathrm{NO}$ and PGs interact to trigger the liver regeneration cascade and that provision of a combination of exogenous NO and PGs can potentiate liver regeneration. An index of initiation of the liver regeneration cascade, $c$-fos messenger (m) RNA expression after PHx, has been used to test this hypothesis. c-Fos mRNA expression has been previously shown to increase following PHx, peaking $15 \mathrm{~min}$ thereafter, and the expression of $c$-fos mRNA is dependent on the degree of PHx performed $(13,14)$. In addition, c-fos mRNA expression increases in response to $\mathrm{NO}$ $(15,16)$ and also to $\mathrm{PGE}_{2}(17,18)$ and $\mathrm{PGI}_{2}(19,20)$. NO signalling also involves stimulation of guanylate cyclase and

Department of Pharmacology and Therapeutics, Faculty of Medicine, University of Manitoba, Winnipeg, Manitoba

Correspondence and reprints: Dr W Wayne Lautt, Department of Pharmacology and Therapeutics, Faculty of Medicine, University of Manitoba,

A210-753 McDermot Avenue, Winnipeg, Manitoba R3E 0T6. Telephone 204-789-3391, fax 204-975-7784,

e-mailwlautt@cc.umanitoba.ca

Received for publication December 12, 2005. Accepted December 13, 2005 
upregulation of cyclic (c) GMP in the liver and other tissues (21). NO signalling via the cGMP pathway is regulated by breakdown of cGMP by phosphodiesterase (PDE) enzymes, specifically PDE type V (22). Inhibition of PDE V by the PDE V-specific antagonist, zaprinast (ZAP) results in an increase in cGMP signalling, and represents an additional potential compound for potentiation of the liver regeneration cascade. Thus, the NO donors, 3-morpholinosydnonimine (SIN-1) and SNAP, the PDE $\mathrm{V}$ antagonist ZAP, $\mathrm{PGE}_{2}$ and $\mathrm{PGI}_{2}$, and various combinations of these, were used to test the hypothesis that NO and PGs interact to potentiate the liver regeneration cascade.

Based on results obtained using the $c$-fos mRNA expression index, NO and PGs were administered to rats immediately following $\mathrm{PHx}$, and $48 \mathrm{~h}$ later, liver weight restoration was measured. This is a critical test of the hypothesis that $\mathrm{NO}$ and PGs can potentiate the liver regeneration cascade, because liver weight restoration after $\mathrm{PHx}$ encompasses the entire liver regeneration cascade, while $c$-fos mRNA expression is only one component. The c-fos mRNA expression index is used as a screening tool to provide information regarding the stimulation of the liver regeneration cascade, and possible compounds that may be used in the potentiation thereof. Liver weight restoration $48 \mathrm{~h}$ after $\mathrm{PHx}$ was chosen as an index because it is known that liver regeneration is $50 \%$ complete within $48 \mathrm{~h}$ of PHx in the rat (23). Thus, administration of NO donors, PGs, ZAP, and combinations of these identified using the c-fos mRNA expression index, was used to test the hypothesis that $\mathrm{NO}$ and $\mathrm{PGs}$ can potentiate the liver regeneration cascade in vivo.

Results presented here indicated that $\mathrm{NO}$ and $\mathrm{PGI}_{2}$ can potentiate the liver regeneration cascade after $\mathrm{PHx}$. These compounds represent possible therapeutic targets for potentiation of the liver regeneration cascade for patients undergoing hepatic resection. Further research is required to determine the optimal doses for administration following hepatic resection.

\section{Animals}

\section{METHODS}

For the acute experiments, male Sprague-Dawley rats, $250 \mathrm{~g}$, were fed standard laboratory chow ad libitum until the day before the experiment, when they were made to fast for $8 \mathrm{~h}$ and then fed for $2 \mathrm{~h}$ before experimentation. For the chronic experiments, male Sprague-Dawley rats, $250 \mathrm{~g}$, were fed standard laboratory chow ad libitum. Animals were treated according to the guidelines of the Canadian Council on Animal Care, and all protocols were approved by the Ethics Committee on Animal Care at the University of Manitoba, Winnipeg, Manitoba.

\section{c-Fos mRNA expression}

Surgical procedure (acute experiments): Briefly, rats were anesthetized using sodium pentobarbital. Tracheotomy was performed, and cannulae were placed in the femoral artery, femoral vein and portal vein for infusion of drugs and anesthetic. Laparotomy was performed, and the animal was allowed to stabilize for $30 \mathrm{~min}$. Drug or saline was then administered, and $\mathrm{PHx}$ or sham procedures were performed at the appropriate time. The left lateral and median lobes of the liver were removed (two-thirds $\mathrm{PHx}$ ) for a brief time, or gently manipulated (sham procedure). The remnant liver was then removed after $15 \mathrm{~min}$ and immediately frozen on dry ice for RNA analysis. Experimental groups were as follows: sham, PHx, sham+SNAP, PHx+SNAP, sham+SIN-1, PHx+SIN-1, sham $+\mathrm{PGE}_{2}, \mathrm{PHx}+\mathrm{PGE}_{2}$, sham $+\mathrm{PGI}_{2}, \mathrm{PHx}+\mathrm{PGI}_{2}$, sham $+\mathrm{ZAP}$ (ZAP; $10 \mathrm{mg} / \mathrm{kg}), \mathrm{PHx}+\mathrm{ZAP}(10 \mathrm{mg} / \mathrm{kg})$, sham+ZAP $(30 \mathrm{mg} / \mathrm{kg})$ and PHx+ZAP (30 mg/kg). SNAP ( $5 \mathrm{mg} / \mathrm{kg} ; 0.2 \mathrm{~mL}$ bolus, intraportal vein administration [IPV] over $2 \mathrm{~min}$ ) (Sigma-Aldrich Canada Ltd), SIN-1 (5 mg/kg; $0.2 \mathrm{~mL}$ bolus IPV over $2 \mathrm{~min}$ ) (Alexis Corporation, USA), $\mathrm{PGE}_{2}(10 \mu \mathrm{g} / \mathrm{kg} ; 0.1 \mathrm{~mL}$ bolus over $1 \mathrm{~min})$ (Sigma-Aldrich Canada Ltd), $\mathrm{PGI}_{2}(10 \mu \mathrm{g} / \mathrm{kg} ; 0.1 \mathrm{~mL}$ bolus IPV over $1 \mathrm{~min}$ ) (Sigma-Aldrich Canada Ltd) or saline ( $0.2 \mathrm{~mL}$ bolus over $2 \mathrm{~min}$ ) were administered and PHx performed immediately thereafter. ZAP (10 mg/kg or $30 \mathrm{mg} / \mathrm{kg} ; 0.05 \mathrm{~mL}$ bolus IPV over $0.5 \mathrm{~min}$ ) was administered and $\mathrm{PHx}$ performed 5 min thereafter.

Based on the results from the initial potentiation experiments (Smith and Lautt, unpublished data), drug combinations included ZAP and/or SNAP and/or $\mathrm{PGI}_{2}$. Concentration, volume and route of administration for the combination drugs were the same as for the individual ones. For administration of the double drug combinations, ZAP was administered first and $3 \mathrm{~min}$ to $4 \mathrm{~min}$ thereafter, either SNAP or $\mathrm{PGI}_{2}$ was administered. In the other combination group, SNAP was administered followed immediately by $\mathrm{PGI}_{2}$. In the triple combination group, ZAP was administered followed by SNAP and then $\mathrm{PGI}_{2}$. PHx was then immediately performed, and 15 min later, the remaining liver was removed and frozen on dry ice for RNA analysis.

RNA isolation and northern blot analysis: RNA analysis has been previously described (4). Briefly, total RNA was extracted using a $3 \mathrm{M} / 6 \mathrm{M}$ lithium chloride/urea solution, centrifuged at $25,000 \mathrm{rpm}$ for $20 \mathrm{~min}$ at $4^{\circ} \mathrm{C}$, and total RNA was extracted using phenol/chloroform. The concentration of the RNA was then determined and $20 \mu \mathrm{g}$ of total RNA was separated by gel electrophoresis under denaturing conditions, transferred to nylon membrane and fixed by ultraviolet crosslinking. The membranes were prehybridized at $42^{\circ} \mathrm{C}$ for $3 \mathrm{~h}$ in prehybridization buffer, and c-fos mRNA was detected using a $1.8 \mathrm{~kb}$ complementary DNA probe labelled by the random prime method, with $\alpha-d C T P^{32} \mathrm{P}$. The membranes were hybridized overnight at $42^{\circ} \mathrm{C}$, washed at $65^{\circ} \mathrm{C}$ and exposed to film, and the density of the c-fos mRNA band was determined by densitometry. c-Fos mRNA expression was reported relative to $18 \mathrm{~S}$ ribosomal RNA. The structure of $c$-fos complementary DNA used was as described by Curran et al (24). Results were analyzed using ANOVA followed by Tukey's post hoc test, with $\mathrm{P}<0.05$ deemed significant.

\section{Liver weight restoration}

Surgical procedure (chronic experiments): Male Sprague-Dawley rats were anesthetized using sodium pentobarbital $(0.1 \mathrm{mg} / 100 \mathrm{~g}$ of $65 \mathrm{mg} / \mathrm{mL}$ solution, intraperitoneal [IP]) and the abdomen was shaved and cleaned with $70 \%$ alcohol and betadine. Laparotomy was performed and drug or saline was administered IP. The left lateral and median lobes were removed (two-thirds $\mathrm{PHx}$ ), or the liver lobes gently manipulated (sham procedure). A microrenathane catheter (MRE-040, Braintree Scientific Inc, USA) filled with saline was placed under the skin, with one end inside the abdominal cavity and the other exiting between the shoulder blades on the back of the rat. The abdomen was sutured shut (muscle then skin layers), using Dexon II, 3-0 (Northland Healthcare Products Ltd, Canada) sutures and ensuring that the catheter was secure. The opening between the shoulder blades was sutured shut, and the catheter secured with sutures. The catheter was capped to allow further IP doses of drug or saline. Ketoprophen (an analgesic, $2.5 \mathrm{mg} / \mathrm{kg}$ ) was administered subcutaneously. The rats were allowed to recover in individual cages placed on heating pads. 
The animals were monitored until they were awake and able to move around the cage. They had access to food and water at all times, with some food pellets placed on the bottom of the cage for easier access. Drug or saline administration $(0.5 \mathrm{~mL}$ bolus IP) took place at $5 \mathrm{~h}$ intervals, three times per day for a total of six doses during the next $48 \mathrm{~h}$. Forty-eight hours after PHx, the rats were sacrificed by pentobarbital anesthetic overdose and the livers removed, slashed and blotted, and weighed. The per cent liver weight restoration after PHx was calculated as follows: $\begin{aligned} & \text { Percentage of liver } \\ & \text { weight restoration }\end{aligned}=\frac{(48 \mathrm{~h} \text { liver weight }[\mathrm{g}]-\text { remnant liver weight }[\mathrm{g}]) \times 100}{\text { Resected liver weight }(\mathrm{g})}$

Remnant liver weight $=$ standard total liver weight $(\mathrm{g})-$ resected liver weight $(\mathrm{g})$

Where the $48 \mathrm{~h}$ liver weight is the weight of the liver $48 \mathrm{~h}$ after $\mathrm{PHx}$; the remnant liver weight is the theoretical remaining liver weight following resection, as calculated above; and resected liver weight is the weight of the left lateral and median lobes removed during PHx. The standard total liver weight was calculated from a regression analysis of the total liver weight versus body weight in control rats $(n=40)$

Results were analyzed using ANOVA followed by Tukey's post hoc test, with $\mathrm{P}<0.05$ deemed significant.

Drug preparation for liver weight restoration experiments: For the experiments involving $c$-fos mRNA expression, SNAP $(5 \mathrm{mg} / \mathrm{kg})$ was dissolved in saline and a $0.2 \mathrm{~mL}$ bolus was infused IPV over $2 \mathrm{~min}$. PGI 2 (10 $\mu \mathrm{g} / \mathrm{kg})$ was dissolved in 95\% ethanol in a stock solution, and diluted with the appropriate amount of saline to achieve the desired concentration. A $0.1 \mathrm{~mL}$ bolus of either PG was infused IPV over $1 \mathrm{~min}$. ZAP was dissolved in $0.15 \mathrm{M}$ sodium hydroxide, and diluted to the appropriate concentration using saline. PHx or sham procedures were performed immediately following SNAP, ZAP or $\mathrm{PGI}_{2}$ administration.

For the liver weight restoration experiments, drugs were prepared as described for the $c$-fos experiments. 6-keto-PGF $1 \alpha$, a stable metabolite of $\mathrm{PGI}_{2}$, was used in the $48 \mathrm{~h}$ liver weight restoration experiments rather than $\mathrm{PGI}_{2}$, due to the short halflife of $\mathrm{PGI}_{2}$. The dose of 6 -keto-PGF $\mathrm{PF}_{1 \alpha}$ was selected based on potentiation of $c-f o s$ mRNA expression using $\mathrm{PGI}_{2}$, and the finding that 6 -keto-PGF ${ }_{1 \alpha}$ was at least $50 \%$ less effective at vasorelaxation of smooth muscle compared with $\mathrm{PGI}_{2}$ (25). Thus, a dose of $20 \mu \mathrm{g} / \mathrm{kg}$ of $6-\mathrm{keto}-\mathrm{PGF}_{1 \alpha}$, double that of $\mathrm{PGI}_{2}$ used in the $c$-fos experiments, was administered. The 6 -keto-PGF ${ }_{1 \alpha}$ was dissolved in $95 \%$ ethanol, and diluted to the appropriate concentration with saline. Doses were based on c-fos mRNA expression experiments, and a volume of $0.5 \mathrm{~mL}$ of drug or drug combination was administered each time. The initial dose was delivered IP at the time of surgery, and supplemental doses were administered by IP injection via the implanted catheter. For each drug or combination, the doses were given at $5 \mathrm{~h}$ intervals, three times per day for two days.

\section{c-Fos mRNA expression}

\section{RESULTS}

To test the hypothesis that $\mathrm{NO}$ and $\mathrm{PGs}$ are possible therapeutic targets to potentiate the liver regeneration cascade, the NO donors, SIN-1 and SNAP, or the PGs, $\mathrm{PGE}_{2}$ and $\mathrm{PGI}_{2}$, were administered immediately before PHx, and c-fos mRNA expression was evaluated. The increase in $c$-fos mRNA expression after PHx (1.36 \pm 0.17 , $\mathrm{n}=5, \mathrm{P}<0.01$ versus sham $[0.34 \pm 0.06, \mathrm{n}=5])$ was potentiated by $\mathrm{PGI}_{2}(2.19 \pm 0.08, \mathrm{n}=4, \mathrm{P}<0.05$ versus $\mathrm{PHx})$ and by the

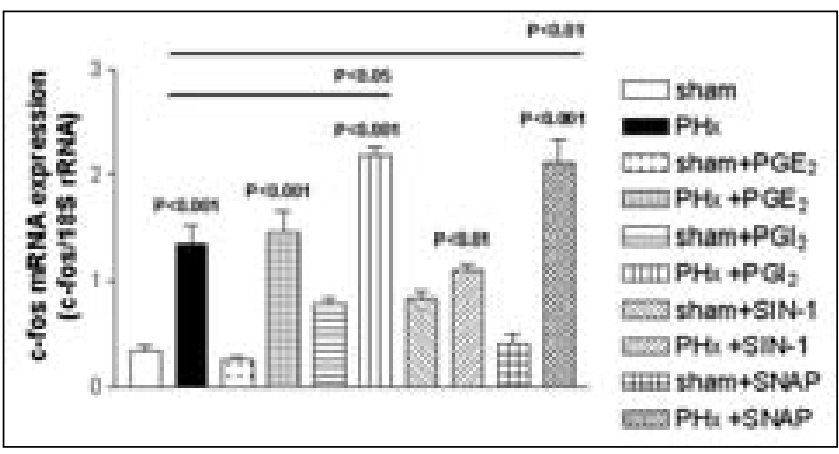

Figure 1) Potentiation of the liver regeneration cascade by nitric oxide and prostaglandins (PGs). The increase in c-fos messenger $(m)$ RNA expression, an index of initiation of the liver regeneration cascade, after partial hepatectomy $(\mathrm{PHx})$ is further potentiated by $\mathrm{PGI}_{2}$ and s-nitroso-n-acetylpenicillamine (SNAP), and not by $\mathrm{PGE}_{2}$ and 3-morpholinosydnonimine (SIN-1). These results provide support for the hypothesis that nitric oxide and PGs are possible therapeutic targets for potentiation of the liver regeneration cascade. ( $\mathrm{PH} x, \mathrm{PH} x+\mathrm{PGE}_{2}$, $\mathrm{PH} x+\mathrm{PGI}_{2}$ and $\mathrm{PH} x+\mathrm{SNAP} \mathrm{P}<0.001$ versus sham; $\mathrm{PH} x+\mathrm{SIN}-1$ $P<0.01$ versus sham; $P H x+P G I_{2} P<0.05$ versus $P H x ; P H x+$ SNAP $P<0.01$ versus $P H x)$ (data shown as mean \pm SEM). rRNA Ribosomal RNA

NO donor, SNAP $(2.12 \pm 0.21, \mathrm{n}=7, \mathrm{P}<0.05$ versus $\mathrm{PHx})$ (Figure 1). There was no potentiation of $c$-fos mRNA expression by $\mathrm{PGE}_{2}(1.45 \pm 0.21, \mathrm{n}=7, \mathrm{P}=$ not significant [NS] versus PHx) or by the NO donor, SIN-1 $(1.12 \pm 0.05, \mathrm{n}=6$, $\mathrm{P}=\mathrm{NS}$ versus $\mathrm{PHx})$. In the sham operated animals livers, neither PGE $(0.27 \pm 0.02, n=4), \mathrm{PGI}_{2}(0.79 \pm 0.06, \mathrm{n}=6)$, SIN-1 $(0.85 \pm 0.06, n=8)$ or SNAP $(0.41 \pm 0.09, n=5)$ caused a significant increase in $c$-fos mRNA expression. Thus, $\mathrm{PGI}_{2}$ and SNAP were able to potentiate $c$-fos mRNA expression, an index of initiation of the liver regeneration cascade, after PHx.

The PDE antagonist, ZAP, which prevents the breakdown of cGMP, was also used as an alternate means of testing the hypothesis that $\mathrm{NO}$ is a possible therapeutic target to potentiate the liver regeneration cascade. Compared with sham, PHx caused an increase in $c$-fos mRNA expression $(1.36 \pm 0.18, n=7$, $\mathrm{P}<0.01$ versus sham $[0.49 \pm 0.06])$, and the PDE antagonist, ZAP $(10 \mathrm{mg} / \mathrm{kg})$, potentiated the increase in $c$-fos mRNA expression after PHx $(2.07 \pm 0.14, n=6, \mathrm{P}<0.001$ versus $\mathrm{PHx})$ (Figure 2). ZAP at a dose of $30 \mathrm{mg} / \mathrm{kg}$ tended to potentiate the increase in $c$-fos mRNA expression after $\mathrm{PHx}$, but the increase was not significant $(2.00 \pm 0.28, n=5, P=N S$ from $\mathrm{PHx})$. The $0.15 \mathrm{M}$ sodium hydroxide and saline vehicle in which ZAP was dissolved had no effect on the increase in c-fos mRNA expression after PHx $(1.21 \pm 0.17, \mathrm{n}=6$; $\mathrm{P}=\mathrm{NS}$ from $\mathrm{PHx})$. In the normal, non-PHx sham operated animals livers, vehicle $(0.44 \pm 0.06, \mathrm{n}=6, \mathrm{P}=\mathrm{NS}$ from sham $)$, ZAP $(10 \mathrm{mg} / \mathrm{kg})$ $(0.55 \pm 0.12, \mathrm{n}=5, \mathrm{P}=\mathrm{NS}$ from sham) or ZAP $(30 \mathrm{mg} / \mathrm{kg})$ $(0.60 \pm 0.09, n=6, P=N S$ from sham $)$ did not cause an increase in $c$-fos mRNA expression. Thus, ZAP is also able to potentiate $c$-fos mRNA expression after PHx.

Based on the above results, it was hypothesized that combinations of SNAP, $\mathrm{PGI}_{2}$ and/or ZAP would further potentiate c-fos mRNA expression after PHx. The increase in $c$-fos mRNA expression after PHx $(1.69 \pm 0.10, \mathrm{n}=5, \mathrm{P}<0.01$ versus sham $[0.41 \pm 0.06, n=5])$ was not further potentiated by the combinations of SNAP+ZAP ( $5 \mathrm{mg} / \mathrm{kg}, 10 \mathrm{mg} / \mathrm{kg})(1.65 \pm 0.20$, 


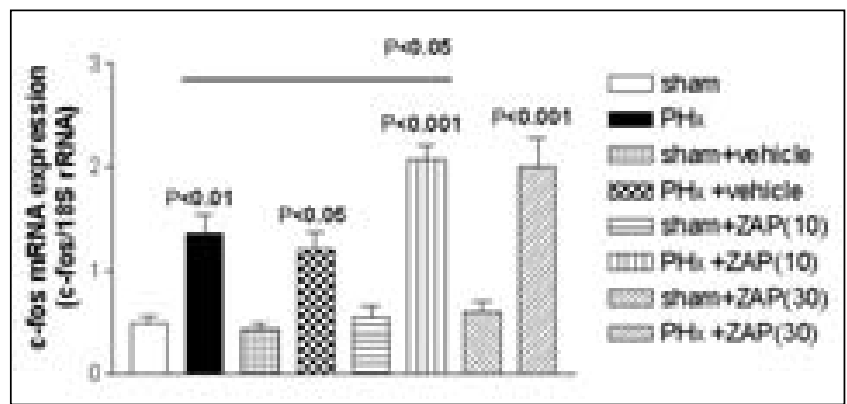

Figure 2) Potentiation of $\mathrm{c}$-fos messenger $(m)$ RNA expression after partial hepatectomy $(\mathrm{PHx})$ by the phosphodiesterase antagonist zaprinast (ZAP). ZAP potentiates the increase in $\mathrm{c}$-fos mRNA expression after $\mathrm{PH}$, providing further support for the hypothesis that nitric oxide is a possible therapeutic target to potentiate the liver regeneration cascade. Also, this suggests that ZAP may potentiate liver weight restoration after $P H x$. ( $P H x P<0.01$ versus sham; $P H x+$ vehicle $P<0.05$ versus sham; $P H x+Z A P(10)$ and $P H x+Z A P(30) P<0.001$ versus sham; $P H x+Z A P(10) P<0.05$ versus $P H x)$ (data shown as mean \pm SEM). rRNA Ribosomal RNA

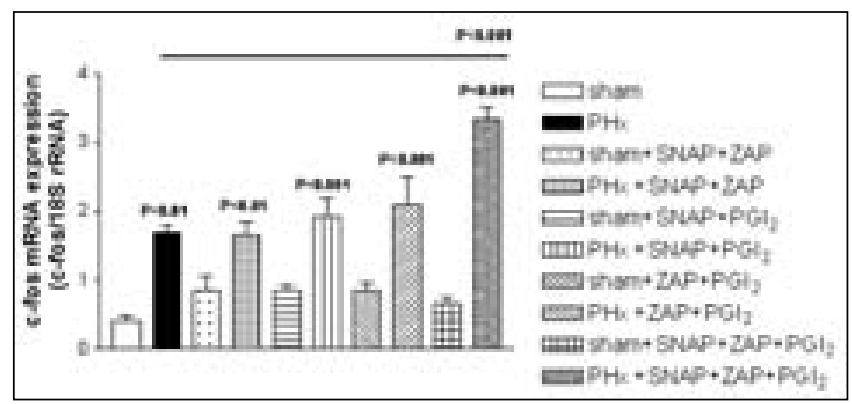

Figure 3) Potentiation of $\mathrm{c}$-fos messenger $(m)$ RNA expression by the combination of s-nitroso-n-acetylpenicillamine (SNAP), zaprinast (ZAP) and prostaglandin (PG) $I_{2}$. c-Fos mRNA expression is increased after partial hepatectomy $(\mathrm{PH} x)$, and this increase is further potentiated by the combination of the nitric oxide donor, SNAP, the phosphodiesterase antagonist, ZAP, and $\mathrm{PGI}_{2}$. These results provide evidence that the combination of these three drugs potentiate c-fos mRNA expression, an index of initiation of the liver regeneration cascade. In addition, these results also suggest that this combination of drugs may potentiate liver regeneration in vivo (data shown as mean \pm SEM). rRNA Ribosomal RNA

$\mathrm{n}=7, \mathrm{P}=\mathrm{NS}$ from PHX), SNAP+PGI $2(5 \mathrm{mg} / \mathrm{kg}, 10 \mu \mathrm{g} / \mathrm{kg})$ $(1.93 \pm 0.27, \mathrm{n}=8, \mathrm{P}=\mathrm{NS}$ from $\mathrm{PHx})$, or $\mathrm{ZAP}+\mathrm{PGI}_{2}(10 \mathrm{mg} / \mathrm{kg}$, $10 \mu \mathrm{g} / \mathrm{kg})(2.09 \pm 0.40, \mathrm{n}=6, \mathrm{P}=\mathrm{NS}$ from $\mathrm{PHx})$ (Figure 3). However, this index was potentiated by the combination of SNAP, ZAP and $\mathrm{PGI}_{2}(3.35 \pm 0.17, \mathrm{n}=6, \mathrm{P}<0.001$ versus $\mathrm{PHx})$. In the normal liver, combinations of SNAP+ZAP $(0.85 \pm 0.20, \quad \mathrm{n}=7, \quad \mathrm{P}=\mathrm{NS}$ from sham $), \quad \mathrm{SNAP}+\mathrm{PGI}_{2}$ $(0.84 \pm 0.08, \mathrm{n}=8, \mathrm{P}=\mathrm{NS}$ from sham $), \mathrm{ZAP}+\mathrm{PGI}_{2}(0.85 \pm 0.12$, $\mathrm{n}=7, \mathrm{P}=\mathrm{NS}$ from sham) or $\mathrm{SNAP}+\mathrm{ZAP}+\mathrm{PGI}_{2}(0.66 \pm 0.10$, $\mathrm{n}=5, \mathrm{P}=\mathrm{NS}$ from sham) had no effect on $c$-fos mRNA expression. Thus, the combination of all three drugs, SNAP, ZAP and $\mathrm{PGI}_{2}$, potentiated $c$-fos mRNA expression after $\mathrm{PHx}$.

\section{Liver weight restoration}

To more fully test the hypothesis that $\mathrm{NO}$ and $\mathrm{PGI}_{2}$ are possible therapeutic targets that could potentiate the liver

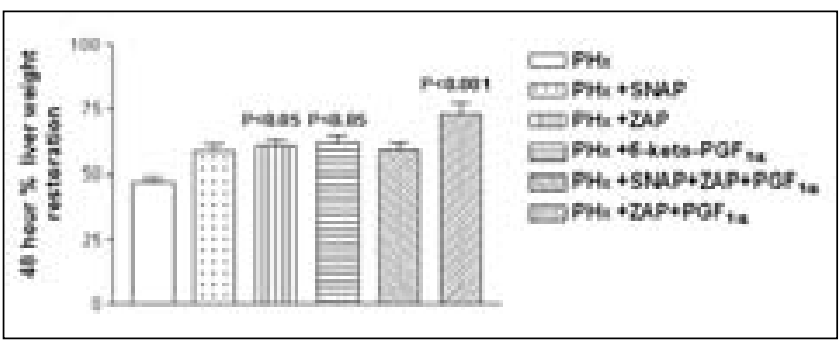

Figure 4) Potentiation of the liver regeneration cascade by zaprinast (ZAP) and prostaglandin (PG) $I_{2}$ in vivo. Liver weight restoration $48 \mathrm{~h}$ after PHx is enhanced by the phosphodiesterase antagonist ZAP, by the PGs, 6-keto-PGF $F_{\alpha}$, a stable metabolite of $\mathrm{PGI}_{2}$, and also by the combination of $Z A P$ and $6-k e t o-P G F_{1 \alpha}$. These results support the hypothesis that nitric oxide and $\mathrm{PGI}_{2}$ are potential therapeutic targets that can potentiate the liver regeneration cascade after $\mathrm{PHx}$ (data shown as mean \pm SEM)

regeneration cascade, a more physiologically relevant index was used. This index is liver weight restoration after PHx. The drugs SNAP, ZAP and $\mathrm{PGI}_{2}$, and the triple combination of SNAP, ZAP and $\mathrm{PGI}_{2}$ were administered to rats immediately before $\mathrm{PHx}$, and continued during recovery after surgery for $48 \mathrm{~h}$. Forty-eight hours after $\mathrm{PHx}$, liver weight was restored by $47.18 \pm 1.75 \%(n=4)$ (Figure 4). Administration of the PDE antagonist ZAP (10 mg/kg, IP), as described above, potentiated liver weight restoration to $60.85 \pm 2.46 \%(\mathrm{n}=8, \mathrm{P}<0.05) \mathrm{com}$ pared with $\mathrm{PHx}$ alone, an increase of $28.97 \%$. Similarly, 6-keto-PGF ${ }_{1 \alpha}(20 \mu \mathrm{g} / \mathrm{kg}, \mathrm{IP})$, a stable metabolite of $\mathrm{PGI}_{2}$, also potentiated liver weight restoration to $61.67 \pm 3.19 \%(\mathrm{n}=6$, $\mathrm{P}<0.05$ ), an increase of $30.71 \%$, after $48 \mathrm{~h}$ versus $\mathrm{PHx}$ only. There was also a trend toward an increase in liver weight restoration $48 \mathrm{~h}$ after $\mathrm{PHx}$ following administration of the $\mathrm{NO}$ donor, SNAP ( $5 \mathrm{mg} / \mathrm{kg}, \mathrm{IP}, \mathrm{n}=7)(58.59 \pm 2.73 \%)$, and following administration of a combination of ZAP $(10 \mathrm{mg} / \mathrm{kg}$, IP), 6-keto-PGF $1 \alpha(20 \mu \mathrm{g} / \mathrm{kg}, \mathrm{IP})$ and SNAP $(5 \mathrm{mg} / \mathrm{kg}$, IP) $(59.09 \pm 3.11 \%, n=7)$. Even though these treatments resulted in increases in liver weight restoration of $24.18 \%$ and $25.24 \%$, respectively, they were not significantly different from PHx only.

Because both ZAP and 6-keto-PGF Pa $_{1 \alpha}$ alone caused an increase in liver weight restoration after $\mathrm{PHx}$, a preliminary experiment was performed in which these two compounds were administered in combination. The combination of ZAP $(10 \mathrm{mg} / \mathrm{kg} \mathrm{IP})$ and 6-keto-PGF $1 \alpha(20 \mu \mathrm{g} / \mathrm{kg}, \mathrm{IP})$ for $48 \mathrm{~h}$ after PHx potentiated liver weight restoration $(73.10 \pm 4.50 \%, n=3$, $\mathrm{P}<0.001$ versus $\mathrm{PHx}$ only), resulting in a $54.94 \%$ increase compared with PHx. However, although the trend is toward further potentiation of liver weight restoration compared with either ZAP or 6-keto-PGF ${ }_{1 \alpha}$ only, the increase was not significant. $\mathrm{NO}$ and $\mathrm{PGI}_{2}$, and the administration of $\mathrm{ZAP}+\mathrm{PGI}_{2}$ in combination, potentiated liver weight restoration after $\mathrm{PHx}$.

\section{DISCUSSION}

$\mathrm{NO}$ and $\mathrm{PGI}_{2}$ potentiated the liver regeneration cascade after PHx. The NO donor SNAP, the PDE V antagonist ZAP, and $\mathrm{PGI}_{2}$ potentiated $c$-fos mRNA expression, an index of initiation of the liver regeneration cascade, after PHx, as did the combination of SNAP, ZAP and $\mathrm{PGI}_{2}$. These results provide 
support for the hypothesis that $\mathrm{NO}$ and $\mathrm{PG}$ are possible therapeutic targets to potentiate the liver regeneration cascade.

In addition, it is interesting that SNAP, ZAP and $\mathrm{PGI}_{2}$ administered individually, or as a triple combination, potentiated c-fos mRNA expression after PHx, while combinations of $\mathrm{SNAP}+\mathrm{ZAP}, \mathrm{SNAP}+\mathrm{PGI}_{2}$ and $\mathrm{ZAP}+\mathrm{PGI}_{2}$ did not. Although different $\mathrm{NO}$ donors have different characteristics (26), including mechanisms of $\mathrm{NO}$ release and degree of production of free radicals (SIN-1 generates superoxide), we currently have no explanation for why SNAP but not SIN-1 potentiated $c$-fos suppression. The implications of these results require further investigation.

c-Fos mRNA expression has proven to be a good index of initiation of the liver regeneration cascade, and has provided excellent information regarding possible therapeutic targets to potentiate liver regeneration. However, liver weight restoration after PHx was chosen as a more physiologically relevant index than $c$-fos mRNA expression, because liver weight restoration encompasses the entire liver regeneration cascade. The end point evaluated using this index provides information on whether $\mathrm{NO}$ or PGs can actually potentiate the liver regeneration cascade in vivo, rather than just one pathway involved in liver regrowth.

Liver weight restoration was evaluated $48 \mathrm{~h}$ after $\mathrm{PHx}$, when $50 \%$ of liver weight is normally restored in the rat (23). Indeed, $47.18 \%$ of the liver weight was restored in rats that underwent PHx only. ZAP and 6-keto-PGF $1 \alpha$, a stable metabolite of $\mathrm{PGI}_{2}$, caused an increase in liver weight restoration $48 \mathrm{~h}$ after $\mathrm{PHx}$, while SNAP and the combination of SNAP, ZAP and 6-keto-PGF ${ }_{1 \alpha}$ also tended to cause an increase in liver weight restoration. In addition, because ZAP and 6-keto-PGF $1 \alpha$ caused a significant increase in liver weight restoration $48 \mathrm{~h}$ after $\mathrm{PHx}$, the effect of the combination of ZAP and 6-keto- $\mathrm{PGF}_{1 \alpha}$ on liver weight restoration was also determined. The combination of ZAP and 6-keto-PGF caused a significant increase in liver weight restoration $48 \mathrm{~h}$ after PHx. However, while this increase tended to be greater than either ZAP or 6-keto-PGF $1 \alpha$ alone, the difference was not significant. Thus, these results demonstrate that $\mathrm{ZAP}, \mathrm{PGI}_{2}$, or a combination of $\mathrm{ZAP}+\mathrm{PGI}_{2}$ can potentiate liver weight restoration after $\mathrm{PHx}$.

It is also interesting that, while the triple combination of SNAP, ZAP and $\mathrm{PGI}_{2}$ potentiated $c$-fos mRNA expression after $\mathrm{PHx}$, the same combination did not cause a significant increase in liver weight restoration. The difference in results could be due to variation between the $c$-fos mRNA expression and liver weight restoration indices. A combination of these three compounds may affect an index involving one triggering pathway in a different manner than the effect on the entire liver regeneration cascade. While the $c$-fos expression provides a useful screening tool, the final validating test rests with determinations using the true end point, liver weight restoration.

\section{Interaction between $\mathrm{NO}$ and PGs in disease conditions}

Administration of $\mathrm{ZAP}, \mathrm{PGI}_{2}$ or a combination of $\mathrm{ZAP}+\mathrm{PGI}_{2}$ could be beneficial to patients undergoing hepatic resection. ZAP, which increases NO action through inhibition of PDE V, plays a role in dilation of capacitance and resistance vessels in the heart (27), and has been shown to be effective in the treatment of conditions such as erectile dysfunction (28). $\mathrm{PGI}_{2}$ is also effective in treating chronic pulmonary hypertension by reducing pulmonary arterial pressure (29), and is being tested for use in patients with peripheral vascular conditions (30). In addition, it has been shown that the combination of $\mathrm{NO}$ and $\mathrm{PGI}_{2}$ can be used to treat some conditions. In patients with pulmonary hypertension, Hill and Pearl (31) found that inhaled $\mathrm{NO}$ and $\mathrm{PGI}_{2}$, administered together, had an additive effect on decreasing pulmonary arterial pressure. Also, Ziesche et al (32), demonstrated that in patients with pulmonary hypertension, who have become refractory to $\mathrm{NO}$ treatment, intravenous epoprostenol ( $\mathrm{PGI}_{2}$ analogue) administration for 13 to 29 months eliminated the refractoriness to $\mathrm{NO}$ treatment. The authors suggest that treatment with $\mathrm{NO}$ and epoprostenol may further improve $\mathrm{O}_{2}$ saturation, cardiac index, mean pulmonary artery pressure and total pulmonary vascular resistance. $\mathrm{PGI}_{2}$ has been administered to patients undergoing orthotopic liver transplant, and it was found that in patients who received $\mathrm{PGI}_{2}$, liver oxygenation was increased and liver damage decreased (33). In addition, $\mathrm{PGI}_{2}$ may play a role in preservation of liver grafts for transplantation, after removal from the donor (34). Thus, administration of NO or a PDE V antagonist (such as ZAP), or $\mathrm{PGI}_{2}$ may play an important role in treating symptoms of some disease conditions. In addition, administration of $\mathrm{NO}$ and/or ZAP and/or $\mathrm{PGI}_{2}$ in combination may further potentiate the effects of these compounds.

\section{Potentiation of liver regeneration by $\mathrm{NO}$ and $\mathrm{PGI}_{2}$}

There has been no suggestion in the literature of administering a combination of ZAP and $\mathrm{PGI}_{2}$ to patients undergoing liver resection to potentiate liver regeneration. The experiments described above are the first results suggesting that therapy with ZAP, which increases the effects of the $\mathrm{NO}$ signalling cascade, $\mathrm{PGI}_{2}$, or a combination of both compounds, will potentiate liver regeneration after surgical resection, and they provide a potential option for patients whose liver must regenerate. Further research is required to determine the optimal dose and dosing schedule to potentiate liver regeneration, but results obtained in this study provide an excellent starting point and the potential for a new therapy to improve liver regeneration.

ACKNOWLEDGEMENTS: The authors acknowledge Dallas Legare for surgical technical assistance. This work was funded by an operating grant from the Canadian Institutes of Health Research. JMSS was funded by a Canadian Institutes of Health Research Studentship.

\section{REFERENCES}

1. Wang HH, Lautt WW. Does nitric oxide (NO) trigger liver regeneration? Proc West Pharmacol Soc 1997;40:17-8.

2. Wang HH, Lautt WW. Hepatocyte primary culture bioassay A simplified tool to assess the initiation of the liver regeneration cascade. J Pharmacol Toxicol Meth 1997;38:141-50.

3. Wang HH, Lautt WW. Evidence of nitric oxide, a flow-dependent factor, being a trigger of liver regeneration in rats. Can J Physiol Pharmacol 1998;76:1072-9.

4. Schoen JM, Wang HH, Minuk GY, Lautt WW. Shear stress-induced nitric oxide release triggers the liver regeneration cascade. Nitric Oxide 2001;5:453-64.

5. Tsujii H, Okamoto Y, Kikuchi E, Matsumoto M, Nakano H. Prostaglandin $\mathrm{E}_{2}$ and rat liver regeneration. Gastroenterology 1993;105:495-9.

6. Lai OF, Chow PK, Tan S, et al. Changes in prostaglandin and nitric oxide levels in the hyperdynamic circulation following liver resection. J Gastroenterol Hepatol 2000;15:895-901.

7. Rudnick DA, Perlmutter DH, Muglia LJ. Prostaglandins are required for CREB activation and cellular proliferation during liver regeneration. Proc Natl Acad Sci USA 2001;98:8885-90. 
8. MacManus JP, Braceland BM. A connection between the production of prostaglandins during liver regeneration and the DNA synthetic response. Prostaglandins 1976;11:609-20.

9. Callery MP, Mangino MJ, Flye MW. Kupffer cell prostaglandin- $E_{2}$ production is amplified during hepatic regeneration. Hepatology 1991;14:368-72.

10. Obolenskaya MY, Vanin AF, Mordvintcev PI, Mulsch A, Decker K. EPR evidence of nitric oxide production by the regenerating rat liver. Biochem Biophys Res Commun 1994;202:571-6.

11. Rai RM, Lee FY, Rosen A, et al. Impaired liver regeneration in inducible nitric oxide synthase-deficient mice. Proc Natl Acad Sci USA 1998;95:13829-34.

12. Carnovale CE, Scapini C, Alvarez ML, Favre C, Monti J, Carrillo MC. Nitric oxide release and enhancement of lipid peroxidation in regeneration rat liver. J Hepatol 2000;32:798-804.

13. Zeini M, Hortelano S, Traves PG, Martin-Sanz P, Bosca L. Simultaneous abrogation of NOS-2 and COX-2 activities is lethal in partially hepatectomised mice. J Hepatol 2004;40:926-33.

14. Moser MJ, Gong Y, Zhang MN, et al. Immediate-early oncogene expression and liver function following varying extents of partial hepatectomy in the rat. Dig Dis Sci 2001;46:907-14.

15. Haby C, Lisovoski F, Aunis D, Zwiller J. Stimulation of the cyclic GMP pathway by NO induces expression of the immediate early genes $c$-fos and junB in PC12 cells. J Neurochem 1994;62:496-501

16. Morris BJ. Stimulation of immediate early gene expression in striatal neurons by nitric oxide. J Biol Chem 1995;270:24740-4.

17. Suda M, Tanaka K, Sakuma Y, et al. Prostaglandin $\mathrm{E}_{2}\left(\mathrm{PGE}_{2}\right)$ induces the $c$-fos and $c$-jun expressions via the $\mathrm{EP}_{1}$ subtype of $\mathrm{PGE}$ receptor in mouse osteoblastic MC3T3-E1 cells. Calcif Tissue Int 2000;66:217-23.

18. Zhuang D, Kawajiri H, Takahashi Y, Yoshimoto T. Suppression of Prostaglandin $\mathrm{E}_{2}$-mediated $c$-fos mRNA induction by interleukin-4 in murine macrophages. J Biochem 2000;127:451-6.

19. Glantschnig H, Varga, F, Klaushofer K. The cellular protooncogenes $c$-fos and egr-1 are regulated by prostacyclin in rodent osteoblasts and fibroblasts. Endocrinology 1996;137:4536-41.

20. Glantschnig H, Varga F, Rumpler, M, Klaushofer K. Prostacyclin $\left(\mathrm{PGI}_{2}\right)$ : A potential mediator of $c$-fos expression induced by hydrostatic pressure in osteoblastic cells. Eur J Clin Invest $1996 ; 26: 544-8$
21. Katsuki S, Murad F. Effects of sodium nitro prusside, nitroglycerin and sodium azide on cyclic GMP levels in various tissues. Clin Res 1977;25:32A. (Abst)

22. Thompson WJ. Cyclic nucleotide phosphodiesterases: Pharmacology, biochemistry and function. Pharmac Ther 1991;51:13-33

23. Higgins GM, Anderson RM. Experimental pathology of the liver: I. Restoration of the liver of the white rat following partial surgical removal. Arch Pathol 1931;12:186-202.

24. Curran T, MacConnell WP, van Straaten F, Verma IM. Structure of the FBJ murine osteosarcoma virus genome: Molecular cloning of its associated helper virus and the cellular monolog of the $V$-fos gene from mouse and human cells. Mol Cell Biol 1983;3:914-21.

25. Levy JV. Prostacyclin-induced contraction of isolated aortic strips from normal and sportaneously hypertensive rats (SHR). Prostaglandins 1980;19:517-25.

26. Freelisch $\mathrm{M}$. The use of nitric oxide donors in pharmacological studies. N S Arch Pharmacol 1998;358:113-22.

27. Ng SS, Pang CC. Zaprinast, a type V phosphodiesterase inhibitor, dilates capacitance vessels in anaesthetised rats. Eur J Pharmacol 1998;351:323-8.

28. Gibson A. Phosphodiesterase 5 inhibitors and nitrergic transmission - from zaprinast to sildenafil. Eur J Pharmacol 2001:411:1-10

29. Abe Y, Tatsumi K, Sugito K, Ikeda Y, Kimura H, Kuriyama T. Effects of inhaled prostacyclin analogue on chronic hypoxic pulmonary hypertension. J Cardiovasc Pharmacol 2001;37:239-51.

30. Fink AN, Frishman WH, Azizad M, Agarwal Y. Use of prostacyclin and its analogues in the treatment of cardiovascular disease. Heart Dis 1999;1:29-40.

31. Hill LL, Pearl RG. Combined inhaled nitric oxide and inhaled prostacyclin during experimental chronic pulmonary hypertension. J Appl Physiol 1999;86:1160-4

32. Ziesche R, Petkov V, Wittmann K, et al. Treatment with epoprostenol reverts nitric oxide non-responsiveness in patients with primary pulmonary hypertension. Heart 2000;83:406-9.

33. Neumann UP, Kaisers U, Langrehr JM, et al. Administration of prostacyclin after liver transplantation: A placebo controlled randomized trial. Clin Transplant 2000;14:70-4.

34. Kishida A, Kurumi Y, Kodama M. Efficacy of prostaglandin $\mathrm{I}_{2}$ analog on liver grafts subjected to 30 minutes of warm ischemia. Surg Today 1997;27:1056-60. 


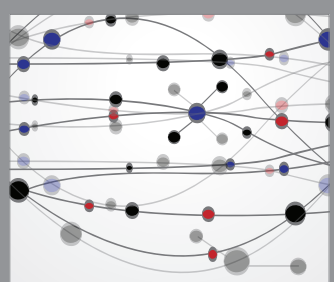

The Scientific World Journal
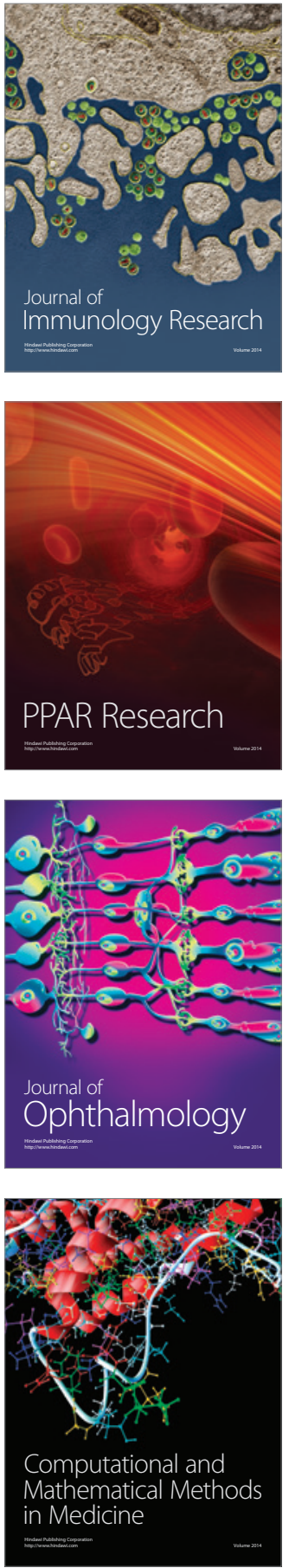

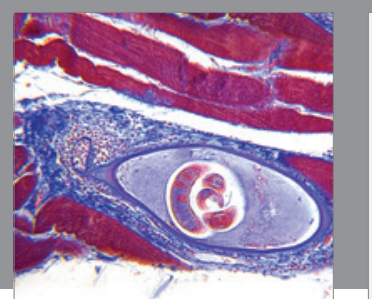

Gastroenterology Research and Practice

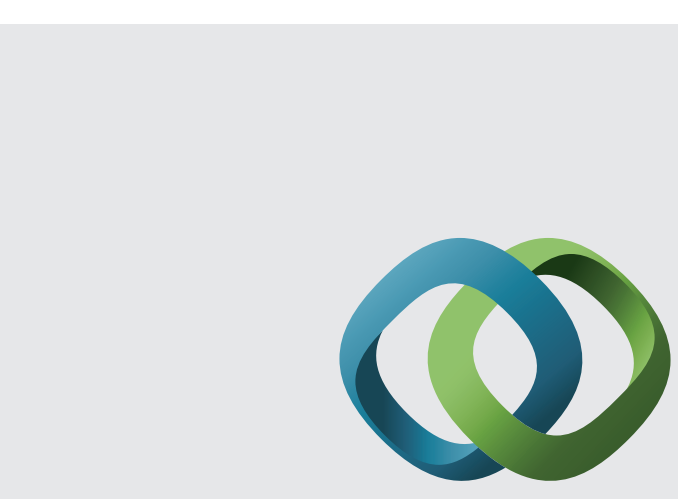

\section{Hindawi}

Submit your manuscripts at

http://www.hindawi.com
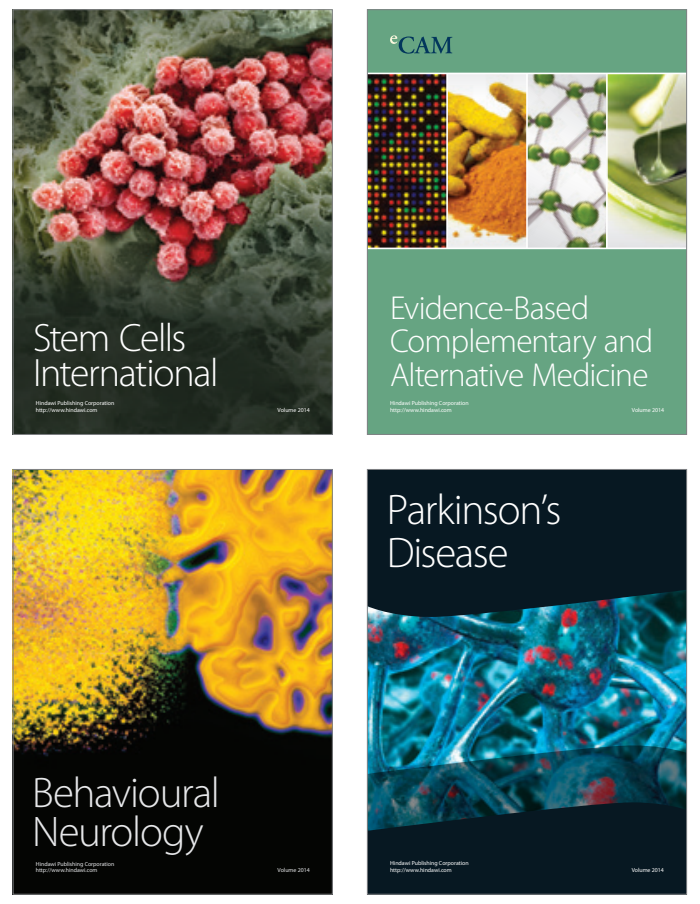
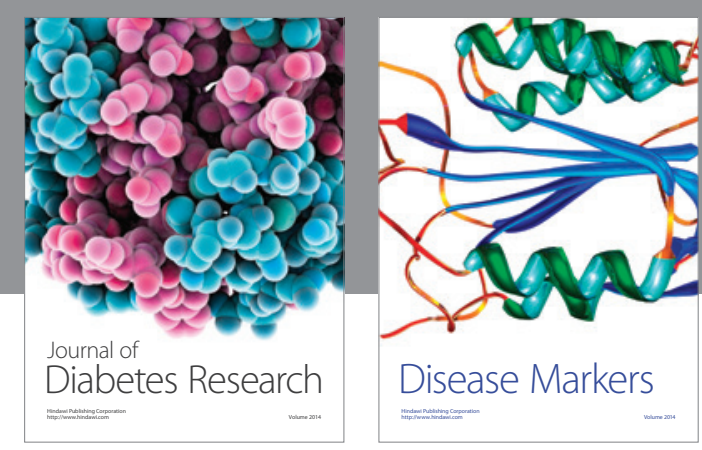

Disease Markers
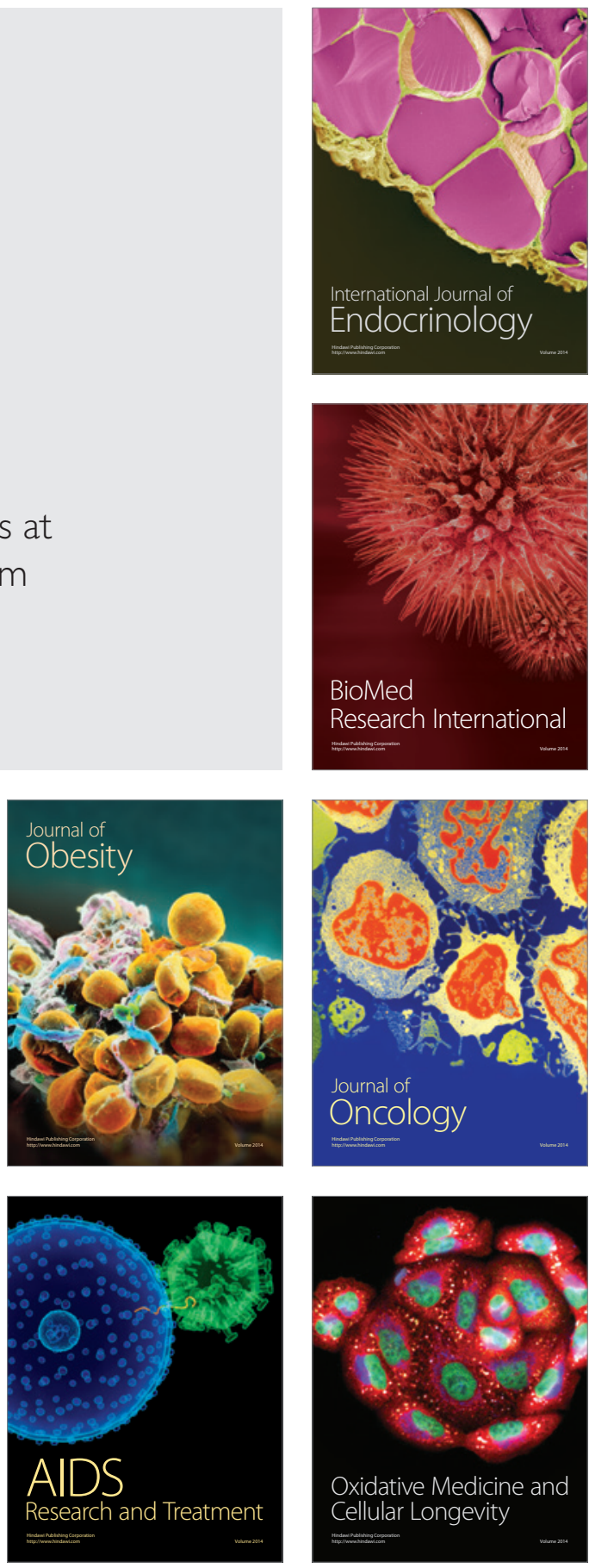